\title{
Liming impacts barley yield over a wide concentration range of soil exchangeable cations
}

\author{
J. E. Holland 1 - P. J. White $\cdot$ J. -N. Thauvin $\cdot$ L. Jordan-Meille $\cdot$ \\ S. M. Haefele $\cdot$ C. L. Thomas $\cdot$ K. W. T. Goulding $\cdot$ S. P. McGrath
}

Received: 19 September 2020/Accepted: 30 December 2020/Published online: 25 April 2021

(C) The Author(s) 2021

\begin{abstract}
Liming has widespread and significant impacts on soil processes and crop responses. The aim of this study was to describe the relationships between exchangeable cation concentrations in soil and the relative yield of spring barley. The hypothesis was that yield is restricted by the concentration of a single exchangeable cation in the soil. For simplicity, we focused on spring barley which was grown in nine years of a long-term experiment at two sites (Rothamsted and Woburn). Four liming rates were applied and in each year the relative yield (RY) and the concentrations of exchangeable cations were assessed.
\end{abstract}

Supplementary Information The online version of this article (https://doi.org/10.1007/s10705-020-10117-2) contains supplementary material, which is available to authorized users.

J. E. Holland $(\bowtie)$

1 Rhynd Farm Cottages,

Leuchars, St Andrews KY16 0DR, UK

e-mail: 2hollandj@gmail.com

P. J. White - J.-N. Thauvin

James Hutton Institute, Dundee DD2 5DA, UK

L. Jordan-Meille

Unité Mixte de Recherche 1391 ISPA, Bordeaux Sciences

Agro, INRAE, 33140 Villenave d'Ornon, France

S. M. Haefele - C. L. Thomas · K. W.

T. Goulding $\cdot$ S. P. McGrath

Department of Sustainable Agriculture Sciences,

Rothamsted Research,

Harpenden, Hertfordshire AL5 2JQ, UK
Liming had highly significant effects on the concentrations of most exchangeable cations, except for $\mathrm{Cu}$ and $\mathrm{K}$. There were significant negative relationships (either linear or exponential) between the exchangeable concentrations of $\mathrm{Mn}, \mathrm{Cd}, \mathrm{Cr}, \mathrm{Al}, \mathrm{Fe}, \mathrm{Cu}, \mathrm{Co}, \mathrm{Zn}$ and $\mathrm{Ni}$ in soil and soil $\mathrm{pH}$. The relationships between $\mathrm{RY}$ and the concentrations of selected exchangeable cations ( $\mathrm{Mn}, \mathrm{Ca}$ and $\mathrm{Al}$ ) were described well using log-logistic relationships. For these cations a significant site effect was probably due to fundamental differences in soil properties. At both sites the concentrations of exchangeable soil $\mathrm{Al}$ were excessive $\left(>7.5 \mathrm{mg} \mathrm{kg}^{-1}\right.$ ) and were most likely responsible for reduced barley yields (where $R Y \leq 0.5$ ) with soil acidification. At Rothamsted barley yield was nonlimited (where $R Y \geq 1$ ) at soil exchangeable $\mathrm{Mn}$ concentrations (up to $417 \mathrm{mg} \mathrm{kg}^{-1}$ ) greater than previously considered toxic, which requires further evaluation of critical Mn concentrations.

Keywords Soil acidity $\cdot$ Exchangeable cations . Critical concentrations - Soil extraction methods . Long-term experiment

\section{Introduction}

Acidic soils are a challenge to agriculture and acidification has been identified as one of the most significant degrading processes of soils at the global 
scale (FAO 2015). Identifying constraints to crop (Holland et al. 2019) and grassland (Stevens and Laughlin 1996) production on acid soils is an important target for current research (Holland et al. 2018). Typically, acidic soils $(<\mathrm{pH} 4.5)$ have elevated concentrations of those exchangeable cations (e.g. $\mathrm{Al}, \mathrm{Mn}$ ), which can restrict plant growth. Consequently, much research has been focused upon the effects of acidity on plant growth, and root growth in particular. Major differences exist between crop types and cultivars in their tolerance to acidity (Fageria et al. 2010; Holland et al. 2018) and there are different perceptions within agriculture on the scale and nature of acidity as a problem.

Liming is a common management strategy to ameliorate acidic soils that has multiple long-term effects on soils, crops and biodiversity (Holland et al. 2018). The main impact of liming is an increase in soil $\mathrm{pH}$ (Goulding et al. 1989) but, the application of limestone can also change the rate and nature of several soil processes. Liming can increase the $\mathrm{Ca}$ and $\mathrm{Mg}$ in the soil solution (Bailey 1995; White and Greenwood 2013) and increase the adsorption on clay surfaces of cations such as $\mathrm{K}, \mathrm{Cu}, \mathrm{Co}$ and $\mathrm{Zn}$ (Bolan et al. 2003). Liming can also reduce the uptake of potentially harmful cations such as $\mathrm{Cd}$ or $\mathrm{Zn}$ by crops in contaminated soils (Hooda and Alloway 1996).

Understanding how the concentrations of soil exchangeable cations affect plant growth has been useful for the nutrient management of crops (White and Greenwood 2013). Previous research has employed numerous different soil extraction methods to determine exchangeable cation concentrations in soil (Rayment and Lyons 2011), which are thought to represent the cation concentrations available to plants (Smolders et al. 2009). Researchers have sought to establish critical concentrations of exchangeable cations in soil resulting in crop deficiencies and toxicities (Hazelton and Murphy 2007; Peverill et al. 1999). For many cations, a wide range of soil exchangeable concentrations have been reported as toxic for the same crop (e.g. barley) (Table 1). This is partly a consequence of the use of different soil extraction methods. Basic soil properties such as texture, mineralogy and organic matter influence the concentrations of cations extracted by a given method (Yin et al. 2002). In addition, the dynamic nature of nutrient processes in the soil, such as leaching, plant uptake, and recycling in the soil biota (White 2013), mean that has been difficult to establish critical concentrations of soil exchangeable cations impacting crop production using soil test methods. For example, Carvalho et al. (2015) reported that it is not possible to predict Mn toxicity to crops using current soil test methods. Nevertheless, with current methods it is possible to determine the most likely nutrients/ elements for which there might be deficiencies or toxicities.

In previous research we tested crop yield effects for lime treatments in a long-term experiment (Holland et al. 2019). This indicated that there were other influences on crop yield, possibly related to cation concentrations. The main aim of this paper was therefore to describe the relationships between exchangeable cation concentrations in soil and the relative yield of spring barley, the most frequently grown crop in the same Long-term Liming Experiment at Rothamsted Research, UK. The hypothesis was that yield is restricted by the concentration of a single exchangeable cation in the soil. In this study the restriction in yield could be due to deficiency or toxicity. Thus the objectives were: $(i)$ to describe the relationships between soil $\mathrm{pH}$ and soil exchangeable cation concentrations, (ii) to describe the relationships between soil exchangeable cation concentrations considered to be toxic or deficient and the relative yield (for all years, $\mathrm{n}=9$ ) of spring barley, (iii) to evaluate the effect of site (soil type) and the concentration of selected exchangeable cations which might be responsible for the reduced yields of barley in acidic soils.

\section{Materials and methods}

Experimental site description, experimental design and climate

The Long-term Liming Experiment was undertaken at two sites at Rothamsted Research (Rothamsted and Woburn farms) between 1962 and 1996. The Rothamsted site was in Sawyers field at Rothamsted Research, Harpenden, Hertfordshire, UK (51.8157 N, $0.3752 \mathrm{~W}$ ). The Woburn site was in Stackyard field (section C) at Woburn Experimental Farm, Husborne Crawley, Bedford, UK (52.0003 N, 0.6149 W), approximately $31 \mathrm{~km}$ from Rothamsted. Four rates (main plot treatments) of limestone were applied as 
Table 1 Published critical concentrations ${ }^{\mathrm{a}}$ of exchangeable cations in the soil $\left(\mathrm{mg} \mathrm{kg}^{-1}\right)$ above which toxicity is observed for barley

\begin{tabular}{lllll}
\hline Cation & Concentration $\left(\mathrm{mg} \mathrm{kg}^{-1}\right)$ & Extraction method & Plant response & Reference \\
\hline $\mathrm{Mn}$ & 30 & $0.01 \mathrm{M} \mathrm{CaCl}_{2}$ & Grain & Slattery and Coventry (1993) \\
$\mathrm{Mn}$ & $24-52$ & $0.01 \mathrm{M} \mathrm{CaCl}_{2}$ & Grain & Dickson et al. (1995) \\
$\mathrm{Cd}$ & 30 & $1 \mathrm{M} \mathrm{MgCl}_{2}$ & Grain & Dudka et al. (1996) \\
$\mathrm{Cd}$ & 60 & $1 \mathrm{M} \mathrm{KCl}$ & Biomass & Wyszkowski and Wyszkowska (2009) \\
$\mathrm{Cr}$ & $100-150$ & - & Biomass & Wyszkowski and Radziemska (2010) \\
$\mathrm{Al}$ & $23-24$ & $0.01 \mathrm{M} \mathrm{CaCl}_{2}$ & Grain & Dolling et al. (1991) \\
$\mathrm{Al}$ & $2.5-4.5$ & $0.01 \mathrm{M} \mathrm{CaCl}_{2}$ & Grain & Anderson and Bell (2019) \\
$\mathrm{Fe}$ & $30 \geq 1000$ & - & - & Peverill et al. (1999) \\
$\mathrm{Cu}$ & 0.3 & $\mathrm{Amm} . \mathrm{oxalate}$ & Grain & Peverill et al. (1999) \\
$\mathrm{Cu}$ & 9.0 & $1 \mathrm{M} \mathrm{NH} \mathrm{NO}_{3}$ & Shoot & Hamels et al. (2014) \\
$\mathrm{Co}$ & 30 & $\mathrm{NA}$ & Shoot & Kapustka et al. (2006) \\
$\mathrm{Zn}$ & $60-280$ & $1 \mathrm{M} \mathrm{NH} \mathrm{NO}_{3}$ & Shoot & Hamels et al. (2014) \\
$\mathrm{Ni}$ & 28 & $\mathrm{NA}$ & Shoot & Kapustka et al. (2006) \\
\hline
\end{tabular}

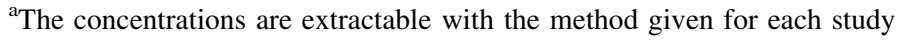

ground chalk $\left(\mathrm{CaCO}_{3}\right)$. The liming treatments were control (zero lime), and low (L), medium (M) and high (H) rates of lime. Over the course of the experiment (35 years duration) the total amounts added were 15 and $9 \mathrm{t} \mathrm{CaCO} 3 \mathrm{ha}^{-1}$ for the $\mathrm{L}$ treatment, 24.5 and 25.5 for the $\mathrm{M}$ treatment and 52.5 and 45.5 for the $\mathrm{H}$ treatment for Rothamsted and Woburn respectively. Lime was applied on similar dates at each site and in six separate applications: twice in 1962 and once in 1978, 1981, 1982 and 1986. A detailed description of the experimental sites, including information on the experimental design, the crops grown, and some aspects of the management are provided by Holland et al. (2019). Selected soil properties for the Rothamsted and Woburn sites are given in Table S1. Additional data and descriptions of these soils, including their mineralogy, are available for Rothamsted (Avery and Catt 1995; Tye et al. 2009; Weir et al. 1969) and Woburn (Anon 1977; Catt et al. 1980).

\section{Soil chemical analysis}

Soil exchangeable cation concentrations were determined on selected soil samples from the Rothamsted soil sample archive. Research by Blake et al. (2000) showed that changes in the concentrations of exchangeable cations in the stored samples from the sample archive were minimal. Soil exchangeable chemical Soil exchangeable chemical analyses were undertaken on samples from all liming treatments that were collected in the following years: 1964, 1967, 1974, 1979, 1983 and 1989. Soils were extracted using a $1 \mathrm{M} \mathrm{NH}_{4} \mathrm{NO}_{3}$ solution (Rhoades 1982). Concentrations of exchangeable cations were assayed using inductively coupled plasma optical emission spectrometry (ICP-OES). The detection limit was calculated as $3 \times$ the standard deviation of the blanks and the quantification limit was calculated as $10 \times$ the standard deviation of the blanks. The effective cation exchange capacity (ECEC) was calculated from the sum of the charges of exchangeable cations $\left(\mathrm{Al}^{3+}\right.$, $\mathrm{Ca}^{2+}, \mathrm{Mg}^{2+}, \mathrm{K}^{+}$and $\mathrm{Na}^{+}$, but excluding $\mathrm{H}^{+}$) and expressed as $\mathrm{cmol}(+)$ per $\mathrm{kg}$ soil using samples from six years $(1964,1967,1974,1979,1983,1989)$ from the medium liming treatment. During the long-term liming experiment the soil $\mathrm{pH}$ was measured in $1: 2.5$ soil: water suspensions using a standard electrode and $\mathrm{pH}$ meter. Crop grain yields have been standardised and are reported at 85 percent dry matter. Further details on the field sampling and soil sample analysis are available (Bolton 1977; eRA 2017; Holland et al. 2019).

Data analysis

Analysis of variance (ANOVA) was used to test the soil exchangeable cation concentrations for main (e.g. lime) treatment effects on spring barley. Data analysis 
was undertaken in a step-wise manner to investigate the relationships between crop yield for spring barley and the concentrations of exchangeable cations. Spring barley was grown in nine years at both sites during the long-term liming experiment (1962-1996). Because the concentration of exchangeable cations in soil was only measured for one year (1967) when spring barley was grown, it was necessary to estimate the concentrations of exchangeable cations for the other eight years when spring barley was grown (1965, 1966, 1970, 1971, 1972, 1973, 1978, 1985). The concentrations were estimated from the relationships between the concentrations of exchangeable cations in the soil and soil $\mathrm{pH}$ which are based equations are given in Table S2 and these data are shown in Fig. 2.

A standard linear and nonlinear regression analysis was used to explore the relationship between the soil $\mathrm{pH}$ and the concentrations of exchangeable cations in soil. The basic principle adopted was to use the most simple function available to describe the data, e.g. for $\mathrm{pH}-\mathrm{Mn}$ a linear equation was used, but for $\mathrm{pH}-\mathrm{Al}$ an exponential function was selected. Several different functions were tested and the one with the best fit was selected and the relevant metrics $\left(P\right.$ value, $\mathrm{R}^{2}$ value and parameter estimates with SE) were calculated accordingly. For $\mathrm{Mg}$ and $\mathrm{K}$, there were no clear or obvious relationships with soil $\mathrm{pH}$ and these were excluded from further analyses.

The relationship between the grain yield and soil $\mathrm{pH}$ were examined using a log-logistic function (four parameter):

$f(y)=c+\frac{d-c}{1+\exp (b(\log (x)-\log (e)))}$

where $y=$ yield, $x=$ soil $\mathrm{pH} ; b=$ slope, $c=$ lower limit and $d=$ upper limit of yield $\left(\mathrm{Y}_{\mathrm{ul}}\right) ; e=\mathrm{EC50}$ (the effective concentration half way (50\%) between $c$ and d). At each experimental site and for each year $Y_{u l}$ was determined independently. Relative yield (RY) was calculated as actual yield ( $y$ ) divided by the $\mathrm{Y}_{\mathrm{ul}}$ (i.e. $y /$ $\mathrm{Y}_{\mathrm{ul}}$ ). RY was used instead of actual yield because of the strong seasonal/year differences. The use of RY effectively standardises yield which makes it easier to analyse data from several years together to test for a treatment effect or undertake regression of a specific relationship. The log-logistic function is a sigmoid curve which is commonly selected to describe plant biomass or height and it is informative as each parameter of the function corresponds to an aspect of plant growth (Archontoulis and Miguez 2015). All soil pH, RY and exchangeable cation data were fitted using the 'drc' package in R (Ritz et al. 2015). Further statistical analyses were performed in $\mathrm{R}$ (R Core Team 2013). Parameter coefficients and the relevant metrics ( $P$ value, $\mathrm{R}^{2}$ value) were calculated accordingly.

The relationship between the concentrations of exchangeable cations in soil and soil $\mathrm{pH}$ was used to estimate concentrations for all years except 1967 when measured concentrations were available. Thus, the relationship between concentration of exchangeable cations in soil and relative yield (RY) was evaluated using Eq. 1, except $y=\mathrm{RY}$ and $x=$ concentration of exchangeable cations in soil $\left(\mathrm{mg} \mathrm{kg}^{-1}\right)$. All data were checked for the assumptions of normality and transformation was not required. The regression analysis was undertaken for each site and year separately. In addition, all years were tested together for each site using Eq. 1. The standard error for each parameter for Eq. 1 was calculated. Testing for the significance between the sites was determined on the $e$ parameter from Eq. 1. The difference was calculated on a $95 \%$ confidence interval where either side of the mean was greater than $1.96 \times \mathrm{SE}$. All regression analysis was undertaken with R (R Core Team 2013).

\section{Results}

Liming and site effects on soil $\mathrm{pH}$

and the concentrations of exchangeable cations in the soil

Treatment (site and lime) effects and their interaction were tested on measurements of soil $\mathrm{pH}$ and the concentrations of exchangeable cations in the soil for 1967 at each site (Rothamsted and Woburn) (Table 2). Site had a significant $(P<0.01)$ effect on soil $\mathrm{pH}$ and on the concentrations of most exchangeable cations except for $\mathrm{Al}$ and $\mathrm{Cu}$. There were highly significant $(P<0.01)$ effects of liming on the concentrations of most exchangeable cations, except $\mathrm{Cu}$ and $\mathrm{K}$, at both sites. The interaction effects between the treatments were mostly significant $(P<0.01)$, except for $\mathrm{Al}, \mathrm{Cu}$, $\mathrm{Zn}, \mathrm{Mg}$ and $\mathrm{K}$ where there was no significant interactions. 
Table 2 The significance level ( $P$ value) for the effects of site and lime treatment and their interaction on soil $\mathrm{pH}$ and on the concentrations of exchangeable cations $(\mathrm{Mn}, \mathrm{Ca}, \mathrm{Cd}, \mathrm{Cr}, \mathrm{Al}$, $\mathrm{Fe}, \mathrm{Cu}, \mathrm{Co}, \mathrm{Zn}, \mathrm{Ni}, \mathrm{Mg}, \mathrm{K}$ ) in soil for 1967 at Rothamsted and Woburn

\begin{tabular}{lrrr}
\hline Element & \multicolumn{1}{l}{ Site } & Lime & Site $\times$ Lime \\
\hline $\mathrm{pH}$ & $<0.001$ & $<0.001$ & $<0.001$ \\
$\mathrm{Mn}$ & $<0.001$ & $<0.001$ & $<0.001$ \\
$\mathrm{Ca}$ & $<0.001$ & $<0.001$ & $<0.001$ \\
$\mathrm{Cd}$ & $<0.001$ & $<0.001$ & $<0.001$ \\
$\mathrm{Cr}$ & $<0.001$ & $<0.001$ & $<0.001$ \\
$\mathrm{Al}$ & 0.769 & $<0.001$ & 0.663 \\
$\mathrm{Fe}$ & 0.001 & $<0.001$ & $<0.001$ \\
$\mathrm{Cu}$ & 0.061 & 0.428 & 0.062 \\
$\mathrm{Co}$ & $<0.001$ & $<0.001$ & $<0.001$ \\
$\mathrm{Zn}$ & 0.028 & $<0.001$ & 0.023 \\
$\mathrm{Ni}$ & 0.005 & $<0.001$ & 0.006 \\
$\mathrm{Mg}$ & $<0.001$ & $<0.001$ & 0.238 \\
$\mathrm{~K}$ & $<0.001$ & 0.393 & 0.754 \\
\hline
\end{tabular}

The relationship between relative yield (RY) and soil $\mathrm{pH}$

The relationships between $\mathrm{RY}$ and soil $\mathrm{pH}$ were evaluated on nine years of spring barley crops at Rothamsted and Woburn (Fig. 1). There was a large range in soil $\mathrm{pH}$ at both sites with the minimum soil $\mathrm{pH}$
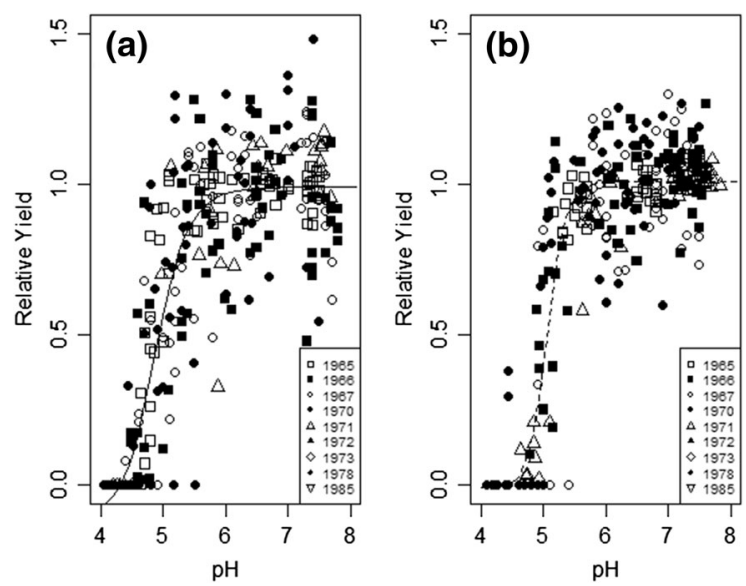

Fig. 1 The relationship between relative yield (RY) and soil $\mathrm{pH}$ in spring barley crops grown in nine years $(1965,1966,1967$, 1970, 1971, 1972, 1973, 1978, 1985) at a Rothamsted and b Woburn; parameter coefficients for the regression can be found in Table 3 approaching 4 and the maximum $\mathrm{pH}$ approaching 8 . Both sites had a wide range of RY values from zero (failed crops) to $>1.3$ (high yielding crops). The fourparameter log-logistic function (Eq. 1) fitted the relationship between $\mathrm{RY}$ and $\mathrm{pH}$ for both sites. The Rothamsted data had slightly greater variability than the Woburn data and included more outlier values. Parameter coefficients for the log-logistic relationship between $\mathrm{RY}$ and $\mathrm{pH}$ are given in Table 3. The EC50 value for Woburn $(\mathrm{pH}=5.06)$ was significantly $(P<0.05)$ greater than the EC50 value at the Rothamsted $(\mathrm{pH}=4.88)$ site.

The relationships between soil $\mathrm{pH}$ and the concentrations of exchangeable cations in the soil

The relationships between the concentrations of exchangeable cations in the soil and soil $\mathrm{pH}$ were described by either: (i) linear or (ii) exponential functions (Fig. 2). The equations describing these relationships and the associated statistical metrics $\left(P\right.$ value and $\mathrm{R}^{2}$ ) are given in Table $\mathrm{S} 2$. There was no relationship between soil $\mathrm{pH}$ and $\mathrm{Mg}$ or between soil $\mathrm{pH}$ and $\mathrm{K}$ (Fig. 2) and thus no equation is given in Table $\mathrm{S} 2$ for $\mathrm{Mg}$ or $\mathrm{K}$. For three exchangeable cations $(\mathrm{Mn}, \mathrm{Cd}$ and $\mathrm{Cr}$ ) there was a highly significant $(P<0.001)$ negative linear relationship with soil $\mathrm{pH}$ at both sites. In contrast, there was a positive relationship between soil $\mathrm{pH}$ and the concentration of $\mathrm{Ca}$. For the concentrations of all exchangeable cations, except $\mathrm{Zn}$, the nature (form) of their relationships with soil $\mathrm{pH}$ was the same at both sites. There was a significant difference between the sites in the form of the relationship between soil $\mathrm{pH}$ and the concentration of exchangeable $\mathrm{Zn}$. At Woburn there was a linear relationship between soil $\mathrm{pH}$ and the concentration of exchangeable Zn, while at Rothamsted there was an exponential relationship (Fig. 2). There were five exchangeable cations ( $\mathrm{Al}, \mathrm{Fe}, \mathrm{Cu}, \mathrm{Co}$, $\mathrm{Ni}$ ) where an exponential function described the relationship with soil $\mathrm{pH}$ at both sites (Fig. 2). For $\mathrm{Ni}$ there was no significant difference $(P>0.05)$ between the sites in the relationship between soil $\mathrm{pH}$ and exchangeable $\mathrm{Ni}$, however there were small differences for the other four cations. 
Table 3 Log-logistic (Eq. 1) parameter coefficients for the relationships between soil $\mathrm{pH}$ and relative yield (RY) of spring barley crops grown in nine years $(1965,1966,1967,1970,1971,1972,1973,1978,1985)$ at Rothamsted and Woburn

\begin{tabular}{lllll}
\hline Site & B (Slope) & c (Lower Limit) & d (Upper Limit) & e (EC50 $)$ \\
\hline Rothamsted & $-18.6(3.1)$ & $-0.10(0.08)$ & $0.99(0.02)$ & $4.88(0.06)$ \\
Woburn & $-33.6(6.4)$ & $-0.01(0.05)$ & $1.01(0.01)$ & $5.06(0.03)$ \\
\hline
\end{tabular}

Standard error of the mean (where $\mathrm{n}=288$ ) is given in brackets

${ }^{a}$ The effective concentration, i.e. soil $\mathrm{pH}$ at $50 \% \mathrm{RY}$
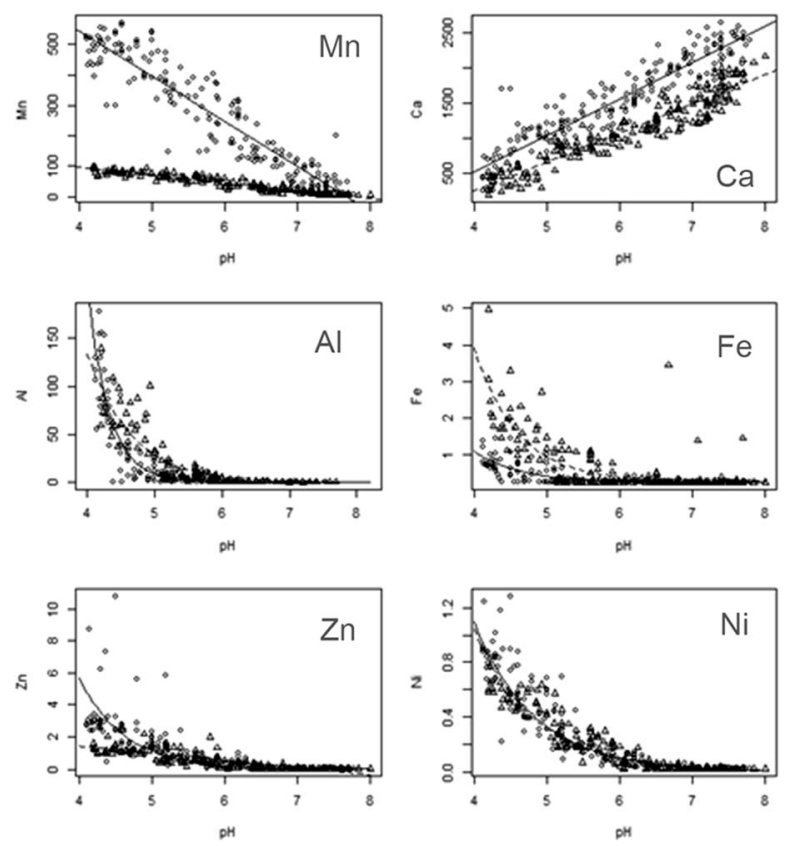

Fig. 2 The relationship between the concentrations of the exchangeable cations ( $\mathrm{Mn}, \mathrm{Ca}, \mathrm{Cd}, \mathrm{Cr}, \mathrm{Al}, \mathrm{Fe}, \mathrm{Cu}, \mathrm{Co}, \mathrm{Zn}, \mathrm{Ni}$, $\mathrm{Mg}, \mathrm{K})$ in the soil $\left(\mathrm{mg} \mathrm{kg}^{-1}\right)$ and soil $\mathrm{pH}$ (1: 2.5, soil: water)

Correlations between the concentrations of exchangeable cations in the soil

The correlations between the concentrations of exchangeable cations in the soil were calculated (Table S3). Correlation coefficients were mostly very high, but there was some variation in strength (from 0.48 to 1.00 ) and in direction ranging from positive to negative. There was a negative correlation between the concentration of exchangeable $\mathrm{Ca}$ and the concentrations of all the other exchangeable cations. The correlations between all the other exchangeable cations were positive. The weakest correlations were between exchangeable $\mathrm{Cu}$ and other exchangeable cations at Woburn. There were some differences in the
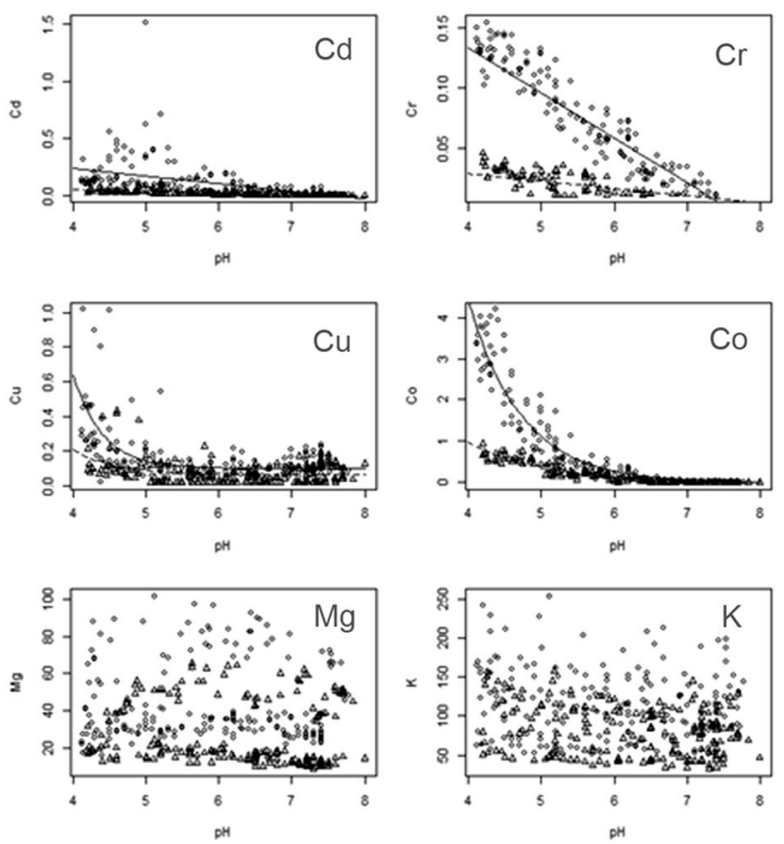

based on measured values from 1964, 1967, 1974, 1979, 1983 and 1989 at Rothamsted (white circle) and Woburn (white triangle)

correlation coefficients between the sites, with the largest differences being between $\mathrm{Al}, \mathrm{Cu}$ and $\mathrm{Zn}$ and other exchangeable cations.

The relationships between relative yield (RY) and the concentration of exchangeable cations in the soil

The relationships between RY and the concentrations of the exchangeable cations in the soil were only evaluated for three cations ( $\mathrm{Al}, \mathrm{Ca}, \mathrm{Mn}$ ) for nine years of spring barley crops at Rothamsted and Woburn (Fig. 3). Other cations (Cd, Cr, $\mathrm{Fe}, \mathrm{Cu}, \mathrm{Co}, \mathrm{Zn}$ and $\mathrm{Ni}$ ) had very low exchangeable concentrations (Fig. 2) which were not considered to be toxic. Thus, the 

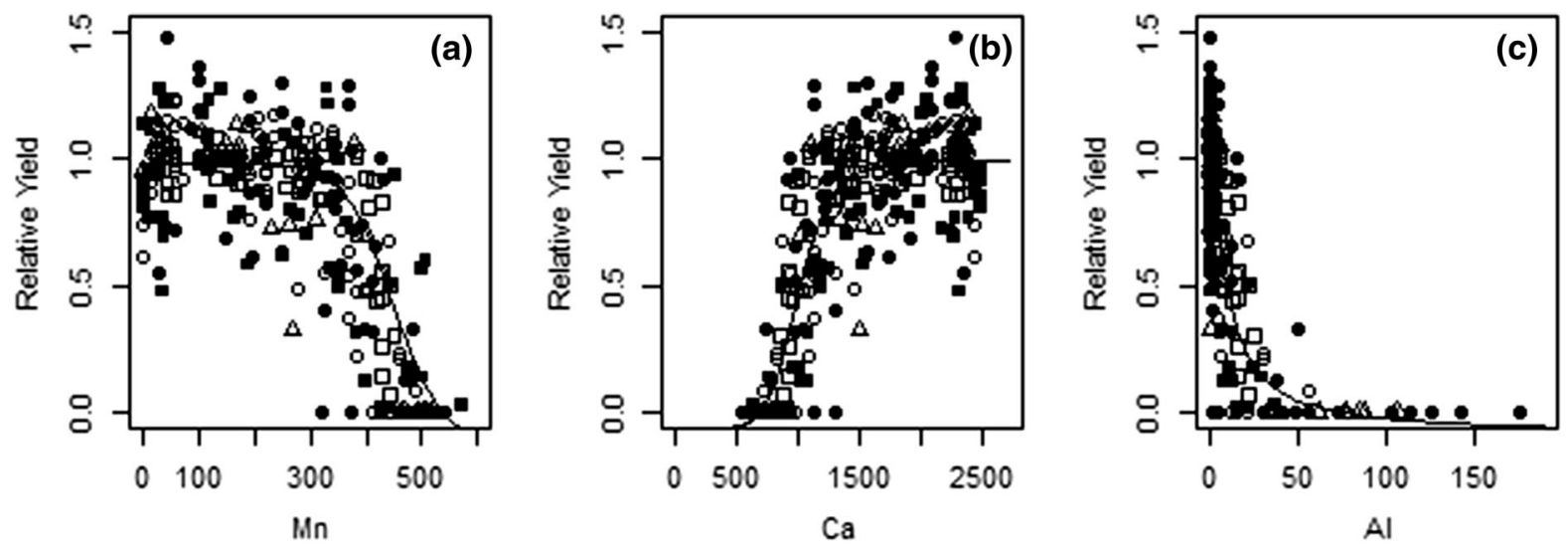
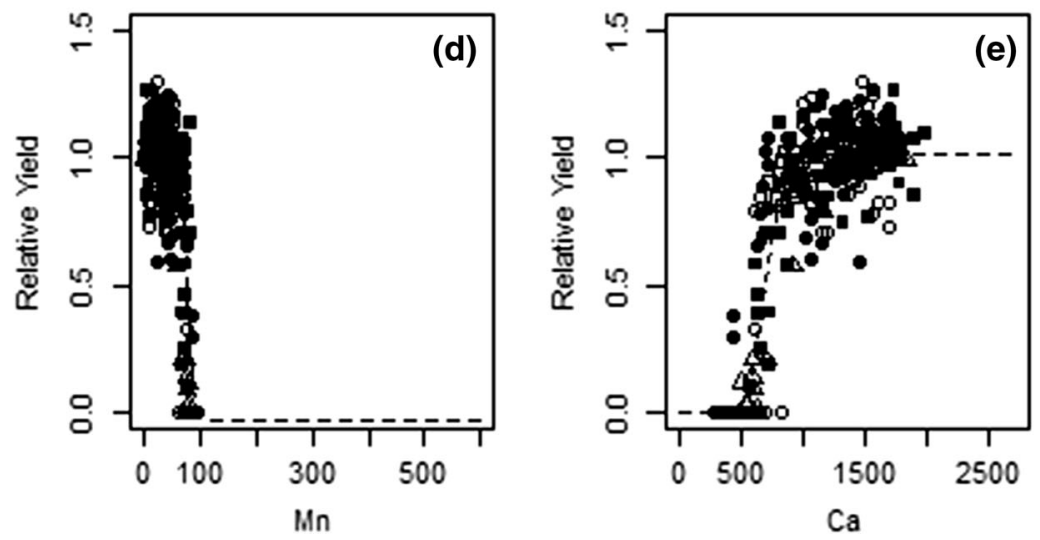

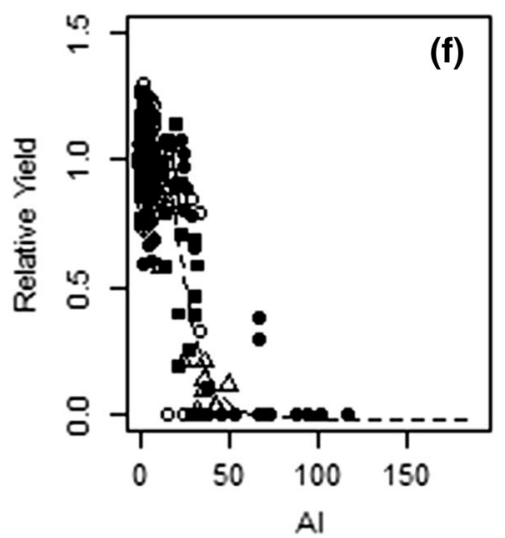

Fig. 3 The relationship between relative yield (RY) and concentrations of exchangeable cations $(\mathrm{Mn}, \mathrm{Ca}, \mathrm{Al})$ in the soil $\left(\mathrm{mg} \mathrm{kg}^{-1}\right)$ for spring barley crops in nine years (white square 1965, black filled square 1966, white circle 1967, black filled circle 1970, white triangle 1971, black filled triangle 1972, white rhombus 1973, black filled rhombus 1978, white inverted

relationships between RY and the concentration of these cations was not evaluated. Indeed, comparison between the concentrations (Fig. 2) and published critical concentrations (Table 1) provides strong support that there was no toxicity from $\mathrm{Cd}, \mathrm{Cr}, \mathrm{Fe}, \mathrm{Cu}, \mathrm{Co}$, $\mathrm{Zn}$ or Ni. Moreover, the concentrations of $\mathrm{K}$ and $\mathrm{Mg}$ were considered neither deficient nor toxic and thus their relationships with RY were not evaluated. There was a wide range in the concentrations of the exchangeable cations at each site and between sites (Fig. 3). For each site the observed variations in concentrations are due to significant differences between years, but overall, the differences between years were less than the differences between the sites. There was a wide range in the RY, from low yielding crops $(\mathrm{RY}<0.3)$ to high yielding crops $(>\mathrm{RY} 1.3)$ triangle 1985) at Rothamsted for RY-Mn (a), RY-Ca (b), RY-Al (c) and at Woburn for RY-Mn (d), RY-Ca (e), RY-Al (f). The concentrations in 1967 were measured and the concentrations for all other years were estimated using the equations given in Table S2

(Fig. 3). At both sites there were cases where the RY was zero indicating that the crop failed (Fig. 3). The four-parameter log-logistic function (Eq. 1) was used to describe the relationships between RY and the concentration of exchangeable cations in the soil (Fig. 3). For all exchangeable cations, except $\mathrm{Ca}$, there was a negative relationship between RY and the concentrations of the exchangeable cations. For $\mathrm{Ca}$, there was a positive relationship between exchangeable Ca concentration and RY (i.e. the greater the exchangeable concentration of $\mathrm{Ca}$ in the soil, the greater RY). There were significant differences between sites in the parameter coefficients of the relationships between RY and the concentrations of exchangeable cations for all exchangeable cations (Table 4). The EC50 values for the relationships 
Table 4 Log-logistic (Eq. 1) parameter coefficients for the relationship between relative yield (RY) of spring barley and soil exchangeable cations ( $\mathrm{Mn}, \mathrm{Ca}, \mathrm{Al})$ for nine years (measured cation concentrations in 1967 and estimated concentrations for 1965, 1966, 1970, 1971, 1972, 1973, 1978, 1985) at Rothamsted and Woburn

\begin{tabular}{llllll}
\hline Cation & Site & $\mathrm{b}$ (Slope) & $\mathrm{c}($ Lower Limit) & $\mathrm{d}($ Upper Limit) & $\mathrm{e}($ EC50 $)$ \\
\hline $\mathrm{Mn}$ & Rothamsted & $9.92(2.0)$ & $-0.17(0.13)$ & $0.98(0.02)$ & $451.6(13.1)$ \\
$\mathrm{Mn}$ & Woburn & $12.39(2.7)$ & $-0.03(0.09)$ & $1.01(0.01)$ & $74.6(1.3)$ \\
$\mathrm{Ca}$ & Rothamsted & $-7.50(1.1)$ & $-0.06(0.06)$ & $1.00(0.02)$ & $1002.6(25.3)$ \\
$\mathrm{Ca}$ & Woburn & $-9.61(1.4)$ & $0.00(0.05)$ & $1.02(0.01)$ & $695.8(12.1)$ \\
$\mathrm{Al}$ & Rothamsted & $1.29(0.23)$ & $-0.08(0.08)$ & $0.98(0.02)$ & $10.8(1.74)$ \\
$\mathrm{Al}$ & Woburn & $4.23(0.85)$ & $-0.02(0.05)$ & $1.01(0.01)$ & $26.0(1.06)$ \\
\hline
\end{tabular}

The estimates are based upon the equations given in Table S2

Standard error of the mean (where $\mathrm{n}=288$ ) is given in brackets

${ }^{\mathrm{a}}$ The effective concentration, i.e. cation concentration at $50 \% \mathrm{RY}$

between RY and exchangeable concentration of $\mathrm{Ca}$ and $\mathrm{Mn}$ were significantly $(P<0.05)$ greater at Rothamsted than at Woburn. In contrast, the EC50 values for the relationships between RY exchangeable Al was significantly $(P<0.05)$ greater at Woburn than at Rothamsted (Table 4).

At Rothamsted the concentration of exchangeable Mn was between 0 and $572 \mathrm{mg} \mathrm{kg}^{-1}$, while at Woburn Mn concentrations ranged from 0 and $100 \mathrm{mg} \mathrm{kg}^{-1}$ (Fig. 3). The log-logistic function (Eq. 1) was fitted to the relationship between RY and the concentration of exchangeable Mn (Fig. 3) and a significant difference $(P<0.05)$ was detected between the sites (Table 4$)$. The EC50 for Mn at Rothamsted was $452 \mathrm{mg} \mathrm{kg}^{-1}$, significantly greater than the EC50 of $75 \mathrm{mg} \mathrm{kg}^{-1}$ at Woburn (Table 4).

Rothamsted had a very wide range of exchangeable Ca concentrations reaching $2500 \mathrm{mg} \mathrm{kg}^{-1}$ (Fig. 3). At Woburn the $\mathrm{Ca}$ concentrations were within a smaller range with few values $>1500 \mathrm{mg} \mathrm{kg}^{-1}$ (Fig. 3). At both sites $\mathrm{RY}$ was $\geq 1.0$ at Ca concentrations between 700 and $>2500 \mathrm{mg} \mathrm{kg}^{-1}$, although plots with a RY of zero were also observed within this range. The relationship between RY and the concentration of exchangeable Ca was positive (Fig. 3) and there was a significant difference $(P<0.05)$ in the relationship between sites (Table 4). The mean EC50 for Ca at Rothamsted was $1000 \mathrm{mg} \mathrm{kg}^{-1}$, while at Woburn it was $695 \mathrm{mg} \mathrm{kg}^{-1}$.

The concentration of exchangeable $\mathrm{Al}$ at Rothamsted was up to $176 \mathrm{mg} \mathrm{kg}^{-1}$ which was a greater range than at Woburn with exchangeable $\mathrm{Al}$ concentrations $<120 \mathrm{mg} \mathrm{kg}^{-1}$ (Fig. 3). At both sites the highest concentrations were associated with zero RY, which indicates a failed crop (Fig. 3). The relationship between RY and the concentration of exchangeable $\mathrm{Al}$ was negative (Fig. 3) and there was a significant effect in the relationship between sites (Table 4). The EC50 for $\mathrm{Al}$ at Rothamsted was $10.8 \mathrm{mg} \mathrm{kg}^{-1}$, significantly less than the EC50 of $26 \mathrm{mg} \mathrm{kg}^{-1}$ at Woburn (Table 4).

Concentrations of exchangeable cations

(a) when yield is maximal and (b) when yield is reduced by soil acidity

The relationships between RY and the concentrations of soil exchangeable cations (Fig. 3) indicate a wide range of exchangeable cation concentrations where crop yield was not limited (where $R Y \geq 1$ ) and where crop yield was restricted $(\mathrm{RY}<0.5)$. The concentrations of soil exchangeable cations that did not limit the yield of barley or were associated with $\mathrm{RY}<0.5$ are given for each site in Table 5.

\section{Discussion}

Site effects on the concentrations of exchangeable cations in the soil

This experiment was undertaken at two sites with distinctly different soil properties (Table S1). A significant site effect was detected on soil $\mathrm{pH}$ and on 
Table 5 Soil exchangeable cations concentrations ${ }^{\mathrm{a}}\left(\mathrm{mg} \mathrm{kg}^{-1}\right)$ observed at Rothamsted and Woburn where: (a) relative yield was maximal and (b) relative yield was $<0.5$ maximal

\begin{tabular}{lllll}
\hline Cation & $\begin{array}{l}\text { (a) Concentrations }\left(\mathrm{mg} \mathrm{kg}^{-1}\right) \text { where yield was } \\
\text { not limited Rothamsted }\end{array}$ & Woburn & $\begin{array}{l}\text { (b) Concentrations }\left(\mathrm{mg} \mathrm{kg}^{-1}\right) \text { associated with } \\
\text { reduced yield Rothamsted }\end{array}$ & Woburn \\
\hline $\mathrm{Mn}$ & $0-417$ & $0-74$ & $>417-572$ & $>74$ \\
$\mathrm{Ca}$ & $1040-2500$ & $690-900$ & $<1040$ & $<690$ \\
$\mathrm{Al}$ & $0-7.5$ & $0-25.7$ & $>7.5$ & $>25.7$ \\
\hline
\end{tabular}

${ }^{\mathrm{a}}$ Concentrations taken from the RY-cation relationships in Fig. 3

the concentration of most exchangeable cations in the soil (i.e. all except for Al) (Table 2). The Rothamsted soil was formed on plateau drift and clay with flints, while the soil at Woburn is formed on colluvium over unconsolidated sandstone (Lower Greensand). Further description of the soil parent material at each site is available (Avery and Catt 1995; Catt et al. 1980) and there is sufficient evidence to indicate that there has been contrasting pedological development at each site. Evaluation of long-term management effects on clay mineralogy at Rothamsted indicate that the greatest changes have been observed on the most acidic soil (control lime plots) (Tye et al. 2009). The limited clay mineralogy of the two soils, presented in Goulding and Loveland (1986; Table 1) shows that both soils contain mica and 'Expansible' clay minerals (interstratified mica-smectite), but with the latter dominant in the Woburn soil. However, the fundamental contrast between the soils is texture. The Rothamsted soil has greater clay and silt content and the Woburn soil is sandier (Table S1). This difference in texture corresponds with the greater cation exchange capacity of the Rothamsted soil compared to the Woburn soil, despite the dominance of 'Expansible' minerals in the latter. Both sites were subject to the same liming treatments which provided a large range in exchangeable cation concentrations. Soils with a larger ECEC have a stronger buffering ability and are comparatively less prone to leaching (Rowell 1994). The fundamental differences between the soils described above probably account for the observation that the Rothamsted soil had significantly greater concentrations of most of the exchangeable cations (i.e. $\mathrm{Mn}, \mathrm{Ca}$, $\mathrm{Cd}, \mathrm{Cr}, \mathrm{Cu}, \mathrm{Co}, \mathrm{Zn}, \mathrm{Mg}$ and $\mathrm{K}$ ) than the Woburn soil (Fig. 2). In contrast, the Woburn soil had greater concentrations of exchangeable $\mathrm{Al}$ and $\mathrm{Fe}$ than the Rothamsted soil (Fig. 2). Site differences in exchangeable cation concentrations are also influenced by the exact composition of cations, which influences whether divalent cations such as $\mathrm{Mg}^{2+}$ or $\mathrm{Ca}^{2+}$ are displaced by trivalent cations such as $\mathrm{Al}^{3+}$ or $\mathrm{Fe}^{3+}$ (White 2013). Differences in all these soil properties explain why there was a soil-type specific equation to describe the relationship between the soil $\mathrm{pH}$ and the concentrations of exchangeable cations in the soil (Table S2). However, according to the hypothesis proposed in the Introduction, if there is a unique concentration of a single exchangeable cation in all soils that results in toxicity to crops, then the EC50 value would be the same for both the Rothamsted and Woburn soils.

The impact of soil type on the relationship between RY and the concentrations of exchangeable cations in the soil

There was a significant site effect on the relationship between RY and the concentrations of exchangeable $\mathrm{Mn}, \mathrm{Ca}$ and $\mathrm{Al}$ (Fig. 3, Table 4). Several studies have indicated that the critical concentrations of soil exchangeable cations resulting in toxicity to crops can differ between soil types. For example, the critical concentrations of exchangeable $\mathrm{Al}$ differ between soil types (Abdulaha-Al Baquy et al. 2018; Adams 1984). These differences are presumably related to inherent differences in soil properties. Such variability in critical concentrations of exchangeable cations between soil types presents a major challenge in the development of a diagnostic approach to identify potential cation toxicities in agricultural soils. Another confounding influence on the development of diagnostic values for cation toxicities in soil is the soil extraction method, which should reflect the cation concentrations available to crops. 
Evaluation of soil extraction method

in the measurement of exchangeable cations

The concentration of an exchangeable cation in soil indicates the amount of that cation held per mass of soil available to a plant (White 2013). The agronomic utility of a soil extraction method is determined by how well it estimates phytoavailable cation concentrations and relates to crop growth parameters, such as biomass or yield. A variety of different soil chemical extractions have been used to determine the concentration of a nutrient in the soil. Much research on contamination of soils has been undertaken using the total concentrations of elements (Warne et al. 2008; White et al. 2012), but total concentrations are poor predictors of potential toxicity to crops (Smolders et al. 2009).

This study used the $\mathrm{NH}_{4} \mathrm{NO}_{3}$ extraction method which is chemically less reactive than other methods and appears suitable for determining the concentrations of most exchangeable cations in soils (Schöning and Brümmer 2008). The $\mathrm{NH}_{4} \mathrm{NO}_{3}$ extraction method compares favourably to other extractable methods used to determine the phytoavailability of a wide range of cations (Mn, Fe, Ca, Mg, K, B, Zn, Mo, Ni, Cu, Cd, $\mathrm{Pb}, \mathrm{As}, \mathrm{Se}, \mathrm{Co}$ ) (Abedin et al. 2012). Indeed, Pueyo et al. (2004) observed that there was $<10 \%$ difference in estimated exchangeable cation concentrations using three common extraction methods $\left(\mathrm{CaCl}_{2}, \mathrm{NaNO}_{3}\right.$, $\mathrm{NH}_{4} \mathrm{NO}_{3}$ ). It is therefore reasonable to assume that measuring exchangeable cations using the $\mathrm{NH}_{4} \mathrm{NO}_{3}$ extraction method gives an adequate estimate of the phytoavailability of cations in a soil that may be influence crop yield. Nevertheless, care must be taken when comparing the EC50 cation concentrations found in our study with the critical exchangeable cation concentrations obtained in studies using alternative methods of soil extraction (Table 1).

Assessment of published critical concentrations for exchangeable cations in the soil

Aluminium and Mn toxicity has been reported to limit crop yields in strongly acidic soils (Conyers et al. 1991). Previous studies have reported critical concentrations of soil exchangeable cations above which the biomass or yield of barley is reduced (Table 1). These critical concentrations of exchangeable cations can be compared with the observed EC50 values observed in this study (Fig. 3; Table 5). This comparison can serve to identify the cations that are likely to become toxic to barley as the soil is acidified.

Critical concentrations of exchangeable $\mathrm{Al}<5 \mathrm{mg} \mathrm{kg}^{-1}$ have been reported to impact barley yield (Anderson and Bell 2019) and other estimates range up to $25 \mathrm{mg} \mathrm{kg}^{-1}$ (Dolling et al. 1991). The EC50 values for Al reported here were $10.8 \mathrm{mg} \mathrm{kg}^{-1}$ at Rothamsted and $26.0 \mathrm{mg} \mathrm{kg}^{-1}$ at Woburn (Table 4). There are two important differences between these published values and the EC50 values reported in this study: $(i)$ the extraction methods differ, which accounts for at least $10 \%$ of the difference, and (ii) the critical concentration is given for $90 \% \mathrm{RY}$ in the published studies. It is possible that the concentrations of exchangeable Al limited barley yields at both Rothamsted and Woburn. Differences in the EC50 between Rothamsted and Woburn are likely to reflect soil properties, which influence the solubility of $\mathrm{Al}$ and its toxic to plants (Foy 1984). Slattery and Coventry (1993) reported that the critical Al concentration for toxicity was greater soils with a high buffering capacity and high organic carbon content. Moreover, the mineral source of $\mathrm{Al}$ and the quantity of organic matter control the solubility of Al (Conyers 1990) and it is Al solubility which determines the toxicity of $\mathrm{Al}$ to crops. The importance of $\mathrm{Al}$ in the soil was confirmed in the simulation of soil acidification of the Rothamsted soil, in specific for the control (no lime) treatment $\mathrm{pH}<4.5$ (Xu et al. (2020).

The published critical soil concentrations of exchangeable $\mathrm{Mn}$ range from 10 to $52 \mathrm{mg} \mathrm{kg}^{-1}$ (Table 1). These concentrations are much lower than the EC50 value determined at Rothamsted, and slightly lower than the EC50 value determined at Woburn (Fig. 3; Table 4). Indeed, crop yield at Rothamsted was not limited by up to $420 \mathrm{mg} \mathrm{Mn}$ $\mathrm{kg}^{-1}$ (Table 5), which is an order of magnitude greater than the published critical concentrations (Table 1). It is, therefore, possible that barley is not as sensitive to soil exchangeable $\mathrm{Mn}$ concentration as previously thought, especially at Rothamsted (Fig. 3). Differences in the critical exchangeable Mn concentration between soils could result from a variety of soil factors, including aeration and microbial activity, both of which influence the speciation of $\mathrm{Mn}$ and, hence, its toxicity to plants (Foy, 1984). In addition, the solubility of $\mathrm{Mn}$ is controlled by soil $\mathrm{pH}$ and the kinetics of redox reactions (Hernandez-Soriano et al. 
2012). Mn oxidation and reduction is controlled by soil water potential and temperature (Sparrow and Uren 2014). Therefore, given the different basic soil properties (i.e. texture) between the experimental sites (Table S1) it is little surprise there is such a large difference in the Mn concentration which reduces barley grain yield (Table 5).

Hazelton and Murphy (2007) reported that at exchangeable $\mathrm{Ca}$ concentrations $<400 \mathrm{mg} \mathrm{kg}^{-1}$ in the soil $\mathrm{Ca}$ deficiency is possible. Thus, it is possible that the soil exchangeable $\mathrm{Ca}$ concentration limited barley yield at Woburn when the exchangeable $\mathrm{Ca}$ concentration was $<600 \mathrm{mg} \mathrm{kg}^{-1}$ and $\mathrm{RY}<0.5$, although this is unlikely to be the case for the larger exchangeable $\mathrm{Ca}$ concentrations in the Rothamsted soil (Fig. 3, Table 5).

The EC50 values for the relationships between RY and the concentration of exchangeable cations in the soil (Fig. 3; Table 5), together with previous estimates of the critical soil exchangeable cation concentrations (Table 1) suggests that toxic $\mathrm{Al}$ and $\mathrm{Mn}$ concentrations might limit barley yields at both Rothamsted and Woburn.

Further validation is required to determine critical soil concentrations. However the relationship between a crop response (barley RY) and key yield-limiting soil properties (i.e. exchangeable $\mathrm{Al}$ and $\mathrm{Mn}$; Fig. 3) clearly demonstrate the importance of soil acidity on crop production. At low soil $\mathrm{pH}$ there is an increased solubility and thus, decreased adsorption of $\mathrm{Al}$ and $\mathrm{Mn}$ (Holland et al. 2018). In this study exchangeable cations were measured and these are a convenient indicator to assess the impact of $\mathrm{Al}$ and $\mathrm{Mn}$ on plant growth. The evidence (Table 5; Fig. 3) from this study that was used to test the hypothesis (that yield was restricted by the concentration of a single exchangeable cation in the soil) was not conclusive overall. As indicated above additional validation work is required to identify the cation which is most restricting yield. Further measurements include collecting plant tissue and root samples; root measurements have been shown to strongly relate to soil $\mathrm{Al}$ concentration (Valle et al. 2009). Previous studies have reported that toxicity can result from additive or synergistic interactions between cations together. This is termed "mixture toxicity". For example, the concentrations of $\mathrm{Zn}$ and $\mathrm{Cu}$ was toxic on the shoot growth of barley (Hamels et al. 2014). The results (Table 5; Fig. 3) in this study indicate that the combined concentration of $\mathrm{Al}$ and $\mathrm{Mn}$ restricted the yield of barley at both sites. Conyers et al. (1991) found there is a complex interaction between $\mathrm{Al}$ and $\mathrm{Mn}$ in which biochemical processes regulate the plant requirement for $\mathrm{Mn}$ and thus the importance of Mn for plant nutrition ought not to be neglected.

The prediction of relative yield (RY) from soil $\mathrm{pH}$ and three exchangeable cations (Al, Mn, Ca) at Rothamsted and Woburn

The analyses described above evaluated the relationships between RY and the concentrations of each cation separately (Fig. 3). In addition to this approach, an additive linear model can be used to predict the effect on RY from different variables by modelling key soil response variables (i.e. soil $\mathrm{pH}, \mathrm{Al}, \mathrm{Mn}$ and Ca) at Rothamsted and Woburn (Table S4). For these soil variables the $\mathrm{R}^{2}$ was similar at each site, being 0.60 at Rothamsted and 0.67 at Woburn. At each site the effect of the concentration of exchangeable $\mathrm{Al}$ was highly significant $(P<0.001)$ and had the strongest effect of any of the selected soil variables. In comparison, soil $\mathrm{pH}$ and the concentrations of exchangeable $\mathrm{Mn}$ and exchangeable $\mathrm{Ca}$ had much less effect on RY. Nevertheless, there were large differences between the sites in the significance $(P$ values) of the effects of the concentration of exchangeable $\mathrm{Mn}$ and $\mathrm{Ca}$ which was likely due to basic soil properties (Table S1). Thus, while the effect of the concentration of exchangeable Mn was significant $(P<0.05)$ on the sandier soil at Woburn, it had no significant effect on the RY at Rothamsted.

\section{Conclusion}

The long-term liming experiment at Rothamsted and Woburn continues to provide insights of significance for soil-crop nutrient relations that have implications for agronomy. The effect of liming was most evident in the relationship between soil $\mathrm{pH}$ and the concentrations of exchangeable cations, and so on the availability of potentially toxic elements to crops in the soils. Comparison of barley yields with the concentrations of exchangeable cations indicated that $\mathrm{Al}$ and $\mathrm{Mn}$ were most important in limiting crop yield. Liming also strongly influenced the concentrations of other exchangeable cations $(\mathrm{Ca}, \mathrm{Cd}, \mathrm{Cr}, \mathrm{Fe}, \mathrm{Cu}, \mathrm{Co}, \mathrm{Zn}$ 
and $\mathrm{Ni}$ ), but these did not significantly reduce the yield of barley. Fundamental soil properties such as texture play an important role in controlling how liming affects the concentrations of toxic cations such as Al and Mn. Soil types which are sandier (such as the sandy loam at Woburn) are more sensitive to Mn, reducing yield compared to the silty clay loam at Rothamsted. Future research is required to (i) better understand the impacts of soil acidification and liming on crop yield, specifically to resolve the nature of multiple negative soil cation effects such as $\mathrm{Al}$ and $\mathrm{Mn}$; (ii) confirm the observed inferences of $\mathrm{Al}$ and $\mathrm{Mn}$ on yield and to validate the critical exchangeable $\mathrm{Al}$ and $\mathrm{Mn}$ concentrations for a wide range of soils.

Acknowledgements The authors are indebted to the original contribution of John Bolton during the early years of the liming experiment. JEH and PJW were funded by the Scottish Government's Rural and Environment Science and Analytical Services Division (RESAS). SPM was funded in Rothamsted Research's Institute Strategic Programme-Soil to Nutrition (BBS/E/C/000I0310) by the UK Biotechnology and Biological Sciences Research Council (BBSRC). We thank the Lawes Agricultural Trust and Rothamsted Research for data from the e-RA database.

Open Access This article is licensed under a Creative Commons Attribution 4.0 International License, which permits use, sharing, adaptation, distribution and reproduction in any medium or format, as long as you give appropriate credit to the original author(s) and the source, provide a link to the Creative Commons licence, and indicate if changes were made. The images or other third party material in this article are included in the article's Creative Commons licence, unless indicated otherwise in a credit line to the material. If material is not included in the article's Creative Commons licence and your intended use is not permitted by statutory regulation or exceeds the permitted use, you will need to obtain permission directly from the copyright holder. To view a copy of this licence, visit http://creativecommons.org/licenses/by/4.0/.

\section{References}

Abdulaha-Al Baquy M, Li J-Y, Jiang J, Mehmood K, Shi R-Y, $\mathrm{Xu}$ R-K (2018) Critical pH and exchangeable Al of four acidic soils derived from different parent materials for maize crops. J Soils Sedim 18:1490-1499

Abedin J, Beckett P, Spiers G (2012) An evaluation of extractants for assessment of metal phytoavailability to guide reclamation practices in acidic soilscapes in northern regions. Can J Soil Sci 92:253-268
Adams F (1984) Soil acidity and liming. American Society of Agronomy, Madison

Anderson G, Bell R (2019) Wheat grain-yield response to lime application: relationships with soil $\mathrm{pH}$ and aluminium in Western Australia. Crop Pasture Sci 70:295-305

Anon (1977) Geology, soils and land use capability. In: 'Woburn Experimental Farm' Rothamsted Research, pp 35-39. https://doi.org/10.23637/ERADOC-1-153

Archontoulis SV, Miguez FE (2015) Nonlinear regression models and applications in agricultural research. Agron J 107:786-798

Avery BW (1980) Soil classification for England and Wales: higher categories. Technical Monograph 14, Soil Survey of England and Wales, Harpenden, UK

Avery BW, Catt JA (1995) The soil at Rothamsted. Rothamsted Res. https://doi.org/10.23637/ERADOC-1-143

Bailey JS (1995) Liming and nitrogen efficiency: some effects of increased calcium supply and increased soil $\mathrm{pH}$ on nitrogen recovery by perennial ryegrass. Commun Soil Sci Plant Anal 26:1233-1246

Blake L, Goulding KWT, Mott CJB, Poulton PR (2000) Temporal changes in chemical properties of air-dried stored soils and their interpretation for long-term experiments. Eur J Soil Sci 51(2):345-353

Bolan NS, Adriano DC, Curtin D (2003) Soil acidification and liming interactions with nutrient and heavy metal transformationand bioavailability. Adv Agron 78:215-272

Bolton J (1977) Changes in soil pH and exchangeable calcium in two liming experiments on contrasting soils over 12 years. J Agric Sci 89:81-86

Carvalho M, Goss M, Teixeira D (2015) Manganese toxicity in Portuguese Cambisols derived from granite: causes, limitations of soil analyses and possible solutions. Revista de Ciências Agrárias 38:518-527

Catt JA, Weir AH, Norrish RE, Rayner JH, King DW, Hall DGM, Murphy CP (1980) The soils of woburn experiment farm III. Stackyard, Rothamsted Research, http://www.era. rothamsted.ac.uk/

Conyers M (1990) The control of aluminium solubility in some acidic Australian soils. J Soil Sci 41(1):147-156

Conyers MK, Poile GJ, Cullis BR (1991) Lime responses by barley as related to available soil aluminium and manganese. Aust J Agric Res 42:379-390

Dickson T, Aitken R, Moody P (1995) Crop response to amendments on two high manganese soils in southeast Queensland, Plant-Soil Interactions at Low pH: Principles and Management. Springer, Berlin, pp 549-553

Dolling P, Porter W, Robson A (1991) Effect of soil acidity on barley production in the south-west of Western Australia. 2. Cereal genotypes and their response to lime. Aust J Exp Agric 31:811-818

Dudka S, Piotrowska M, Terelak H (1996) Transfer of cadmium, lead, and zinc from industrially contaminated soil to crop plants: a field study. Environ Pollut 94:181-188

eRA (2017) Rothamsted electronic archive. http://www.era. rothamsted.ac.uk (Accessed on 23 February 2017)

Fageria NK, Baligar VC, Jones CA (2010) Growth and mineral nutrition of field crops. CRC Press, New York

FAO I (2015) Status of the world's soil resources (SWSR)-main report. Food and agriculture organization of the United 
Nations and intergovernmental Technical panel on soils, Rome, Italy, p 650

Foy CD (1984) Physiological effects of hydrogen, aluminum, and manganese toxicities in acid soil. Soil acidity and liming 12:57-97

Goulding K, Loveland P (1986) The classification and mapping of potassium reserves in soils of England and Wales. J Soil Sci 37:555-565

Goulding K, McGrath S, Johnston A (1989) Predicting the lime requirement of soils under permanent grassland and arable crops. Soil Use Manag 5:54-58

Hamels F, Malevé J, Sonnet P, Kleja DB, Smolders E (2014) Phytotoxicity of trace metals in spiked and field-contaminated soils: Linking soil-extractable metals with toxicity. Environ Toxicol Chem 33:2479-2487

Hazelton P, Murphy BW (2007) Interpreting soil test resultsWhat do all the numbers mean?. CSIRO Publishing, Melbourne

Hernandez-Soriano MC, Degryse F, Lombi E, Smolders E (2012) Manganese toxicity in barley is controlled by solution manganese and soil manganese speciation. Soil Sci Soc Am J 76(2):399-407

Holland J, Bennett A, Newton A, White P, McKenzie B, George T, Pakeman R, Bailey J, Fornara D, Hayes R (2018) Liming impacts on soils, crops and biodiversity in the UK: a review. Sci Total Environ 610:316-332

Holland J, White P, Glendining M, Goulding K, McGrath S (2019) Yield responses of arable crops to liming-An evaluation of relationships between yields and soil $\mathrm{pH}$ from a long-term liming experiment. Eur J Agron 105:176-188

Hooda P, Alloway B (1996) The effect of liming on heavy metal concentrations in wheat, carrots and spinach grown on previously sludge-applied soils. J Agric Sci 127:289-294

Kapustka LA, Eskew D, Yocum JM (2006) Plant toxicity testing to derive ecological soil screening levels for cobalt and nickel. Environ Toxicol Chem Int J 25:865-874

Peverill KI, Sparrow LA, Reuter DJ (1999) Soil analysis: an interpretation manual. CSIRO, Melbourne

Pueyo M, Lopez-Sanchez J, Rauret G (2004) Assessment of $\mathrm{CaCl}_{2}, \mathrm{NaNO}_{3}$ and $\mathrm{NH}_{4} \mathrm{NO}_{3}$ extraction procedures for the study of $\mathrm{Cd}, \mathrm{Cu}, \mathrm{Pb}$ and $\mathrm{Zn}$ extractability in contaminated soils. Anal Chim Acta 504:217-226

R Core Team (2013) R: A language and environment for statistical computing. R Foundation for Statistical Computing. Available, Vienna

Rayment GE, Lyons DJ (2011) Soil chemical methods-Australiasia. CSIRO Publishing, Melbourne

Rhoades J (1982) Cation exchange capacity, methods of soil analysis, part 2, chemical and microbiological properties. In: Page et al (eds) Agronomy, vol 9. Springer, Berlin, pp 1490-1589

Ritz C, Baty F, Streibig JC, Gerhard D (2015) Dose-response analysis using R. PloS One 10:52

Rowell DL (1994) Soil science-methods and applications. Addison Wesley Longman Limited, Harlow

Schöning A, Brümmer GW (2008) Extraction of mobile element fractions in forest soils using ammonium nitrate and ammonium chloride. J Plant Nutr Soil Sci 171:392-398
Slattery W, Coventry D (1993) Response of wheat, triticale, barley, and canola to lime on four soil types in northeastern Victoria. Aust J Exp Agric 33:609-618

Smolders E, Oorts K, Van Sprang P, Schoeters I, Janssen CR, McGrath SP, McLaughlin MJ (2009) Toxicity of trace metals in soil as affected by soil type and aging after contamination: using calibrated bioavailability models to set ecological soil standards. Environ Toxicol Chem Int J 28:1633-1642

Soil Survey Staff (1999) Soil taxonomy: a basic system of soil classification for making and interpreting soil surveys. 2nd edn, Natural Resources Conservation Service. U.S. Department of Agriculture Handbook, vol 436

Sparrow LA, Uren NC (2014) Manganese oxidation and reduction in soils: effects of temperature, water potential, $\mathrm{pH}$ and their interactions. Soil Res 52(5):483-494

Stevens R, Laughlin R (1996) Effects of lime and nitrogen fertilizer on two sward types over a 10 -year period. J Agric Sci 127:451-461

Tye AM, Kemp SJ, Poulton PR (2009) Responses of soil clay mineralogy in the Rothamsted Classical Experiments in relation to management practice and changing land use. Geoderma 153(1-2):136-146

Valle SR, Carrasco J, Pinochet D, Calderini DF (2009) Grain yield, above-ground and root biomass of Al-tolerant and Al-sensitive wheat cultivars under different soil aluminum concentrations at field conditions. Plant Soil 318(1-2):299-310

Warne MSJ, Heemsbergen D, Stevens D, McLaughlin M, Cozens G, Whatmuff M, Broos K, Barry G, Bell M, Nash D (2008) Modeling the toxicity of copper and zinc salts to wheat in 14 soils. Environ Toxicol Chem Int J 27:786-792

Weir AH, Catt JA, Ormerod EC (1969) Mineralogy of broadbalk soils. Rothamsted Exp Stat Rep 5:13

White RE (2013) Principles and practice of soil science: the soil as a natural resource. Wiley, New York

White PJ, Greenwood DJ (2013) Properties and management of cationic elements for crop growth. In: Gregory PJ, Nortcliff $\mathrm{S}$ (eds) Soil conditions and plant growth. Blackwell Publishing, Oxford, pp 160-194

White PJ, Broadley MR, Gregory PJ (2012) Managing the nutrition of plants and people. Appl Environ Soil Sci 2:51

WRB (2006) World reference base for soil resources world soil resources reports No. 103. FAO, Rome

Wyszkowski M, Radziemska M (2010) Effects of chromium (III and VI) on spring barley and maize biomass yield and content of nitrogenous compounds. Journal of Toxicology and Environmental Health, Part A 73:1274-1282

Wyszkowski M, Wyszkowska J (2009) The effect of soil contamination with cadmium on the growth and chemical composition of spring barley (Hordeum vulgare L.) and its relationship with the enzymatic activity of soil. Fresen Environ Bull 18:1046-1053

Xu D, Carswell A, Zhu Q, Zhang F, de Vries W (2020) Modelling long-term impacts of fertilization and liming on soil acidification at Rothamsted experimental station. Sci Total Environ 713:136249 
Yin Y, Impellitteri CA, You S-J, Allen HE (2002) The importance of organic matter distribution and extract soil: solution ratio on the desorption of heavy metals from soils. Sci Total Environ 287:107-119
Publisher's Note Springer Nature remains neutral with regard to jurisdictional claims in published maps and institutional affiliations. 